\section{Audiology Neuro-Otology}

Audiol Neurootol 2000;5:300

\title{
Giovanni Rossi
}

Giovanni Rossi died on February 16, 2000, in Savona, a town on the Riviera Ligure where he was born on July 12, 1925. After having finished his medical studies in Pisa in 1950, he moved to Turin where he spent all his academic life. After 1 year in the Department of Pathology, he was appointed assistant at the Department of Otolaryngology and then in 1969 professor of audiology at the University of Turin, a position he held until his retirement in 1998.

In Turin he founded the Institute of Audiology and Phoniatrics which became a renowned Italian centre for diagnosis and treatment of hearing and speech disorders. He helped to pioneer cochlear implantology in Italy, and, for some years now, his department has been a teaching centre for Italian audiologists and speech therapists/ pathologists. His dedication to teaching inspired his $M a$ nuale di Otorinolaringoiatria which has been for several generations of Italian medical students the main handbook of otolaryngology.

During his career he published over 150 articles, a number of them in international journals. An expert in pathology and in histology (he was privatdozent in histology), he was one of the first to study the origin and the course of the efferent cochlear and vestibular fibres in the brain stem by using the histochemical reaction to AChE. Interest in anatomy and physiology of the neural systems controlling inflow of sensory information was pursued throughout his career to his very last years when he was still researching into it at a theoretical level.

During the years 1950-1960, he published several papers showing that salts obtained by combining streptomycin and neomycin with glucuronic acid had a reduced ototoxic effect still maintaining, however, satisfactory antibacterial power. Another of his interests was the study of auditory and extra-auditory effects of noise, and on the basis of this he developed rules and tables for the evaluation of hearing disability following noise exposure.

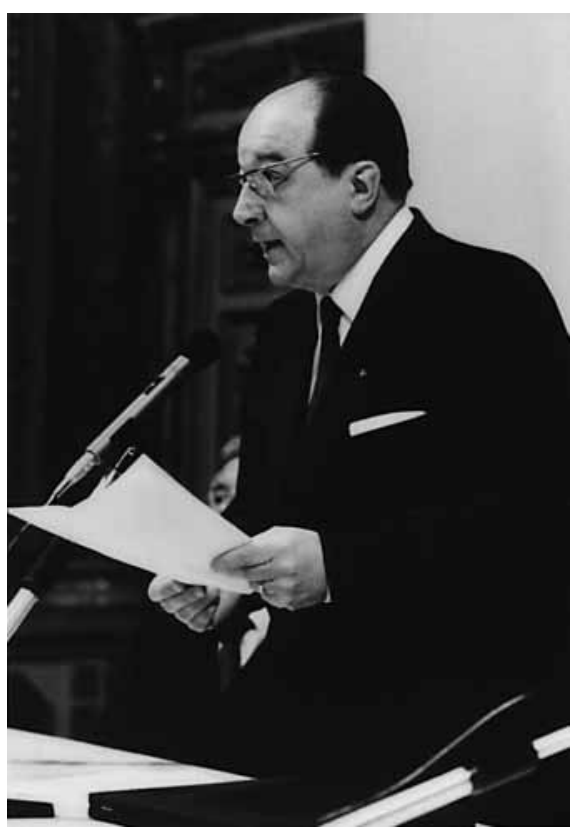

Two noteworthy conferences organized by Giovanni Rossi were the 1983 international conference entitled 'Noise as a Public Health Problem' and the 1987 Collegium ORLAS Meeting, both held in Turin and both very successful. Giovanni Rossi served as President of the Italian Society of Audiology from 1989 to1991.

As a person he was sincere and generous and highly respected by all those who knew him both privately and professionally. To me he has been a very dear friend. To his wife Giovanna, his daughter Elena and his son Ferdinando, professor of human physiology at the University of Turin, go our most sincere condolences.

Salvatore Iurato, Bari

\footnotetext{
KARGER

Fax +41613061234

E-Mail karger@karger.ch www.karger.com

(c) 2000 S. Karger AG, Basel

1420-3030/00/0055-0300\$17.50/0

Accessible online at:

www. karger.com/journals/aud
} 